\title{
Developing instructional materials on mathematics logical thinking through the Indonesian realistic mathematics education approach
}

\author{
Rahmi Purwitaningrum $^{\mathrm{a}, 1}$, Rully Charitas Indra Prahmana ${ }^{\mathrm{b}, 2^{*}}$ (D) \\ a MTs Negeri 4 Kulon Progo, Yogyakarta, Indonesia \\ ${ }^{\mathrm{b}}$ Universitas Ahmad Dahlan, Yogyakarta, Indonesia \\ ${ }^{1}$ rahmipurwitaning@gmail.com; ${ }^{2}$ rully.indra@mpmat.uad.ac.id* \\ * corresponding author
}

ARTICLE INFO

Article history

Received 2020-08-30

Revised 2020-11-23

Accepted 2021-01-29

Published 2021-04-21

Keywords

Design research

Indonesian realistic mathematics

Education

Instructional materials

Linier equations

Logical thinking of mathematics

\section{ABSTRACT}

Instructional materials are one of the essential parts to support the learning process becomes more exciting and meaningful. However, teachers do not yet give more attention to these parts, so that the learning process becomes uninteresting and boring. Therefore, this research aims to produce the instructional materials for the logical thinking of mathematics ability based on Indonesian Realistic Mathematics Education for junior high school students for Grade 8, which is valid and practical. This research used a design research method with the type of development study conducted in two stages, namely preliminary design, and formative evaluation, including self-evaluation, prototyping (expert reviews, one-to-one, and small groups) field tests the research conducted at junior high school. For research subjects, students of class VIII B of junior high school are 29 students. The techniques of data collection used are documentation, walkthrough, interviews, and test. The research data are quantitatively and qualitatively analyzed. The results of data analysis known that this research produces the logical thinking of mathematics for instructional materials based on Indonesian Realistic Mathematics Education on the content of linear equations of two variables that are valid, practical, and have potential effects. In this case, mathematics instructional materials in students' worksheets based on Indonesian Realistic Mathematics Education have been content valid, constructive, and language from expert validation at the expert review stage. In contrast, the mathematics student worksheets based on Indonesian Realistic Mathematics Education have been practically obtained from revisions results of one-to-one and small group. Furthermore, the prototype of instructional materials in the form of student worksheets has potential effects to improve the logical thinking of mathematics ability for students.
This is an open access article under the CC-BY-SA license.

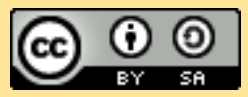

\section{Introduction}

One of the mathematics learning purposes in school is that students can use reasoning on patterns and traits, manipulate mathematics in generalizing, compile evidence, or explain mathematical ideas and statements [1]. It can be seen from the ability to think logically, critically, systematically, and appreciate mathematics' usefulness in solving problems in daily life [2], [3]. Furthermore, Asis, Arsyad, and Alimuddin [4] stated that people with mathematics logical intelligence could manage logic and numbers with the main activities of logical thinking, counting, patterning relation, and solving problems. Therefore, logical thinking needs to be developed in mathematics learning. 
Logical thinking skills need to be developed because they can help students improve their ability to understand mathematics [5], [6]. It is still a problem until now because most students memorize concepts without understanding and cannot use the idea if given rather complex issues. It can be shown from most students who are still having difficulties if given a different question from the usual questions. Similarly, what was disclosed by Usdiyana, Purniati, Yulianti, and Harningsih [7] that the teacher gave examples of problems followed by providing practice questions that were routine less practice reasoning. The learning approach used is still conventional. Conventional mathematics teaching and learning approaches that emphasize direct presentation, less allow students to shape the ability to think logically, and less give flexibility for students to construct their knowledge through interaction with their environment [8], [9]. Furthermore, learning resources' usefulness is not suitable yet with the learning outcomes [10]. Another thing that causes students difficulties is that mathematics learning is less meaningful, so students often have problems applying mathematics to real-life situations [11]. Therefore, the approach that is used is still not suitable yet.

To resolve this problem, needs method, strategy, approach, or learning models that correct to be applied in mathematics learning. One approach expected to improve students' logical thinking skills is Realistic Mathematics Education (RME), or in Indonesia, this approach is familiar with Indonesian Realistic Mathematics Education [12], [13]. Gravemeijer [14] states that in RME learning, three principles can be used as a reference for instructional design research, namely Guided reinvention and progressive mathematizing, didactical phenomenology, and self-developed models. Besides, RME also has five characteristics in the learning process, namely phenomenological exploration or the use of contexts, the use of the models or bridging by vertical instruments, the use of the students owns productions and constructions or student's contribution, the interactive character of the teaching process or interactivity, and the intertwining of various learning strands [15-17]. This approach gives a positive influence on mathematics learning on students' concepts understanding and logical thinking of students [18], [19]. Therefore, the researcher will apply learning that can make students think of mathematics logically so that they can understand the mathematics concepts by using the approach of Indonesian Realistic Mathematics Education but will be packaged in instructional materials.

The instructional materials that developed in this research are student worksheets. Prastowo [20] said that the Student Worksheet is a printed instructional material in the form of a paper sheet containing content, summaries, and instructions on implementing learning tasks that students must do, which refers to the essential competencies that must be achieved. However, the instructional materials that existed for the most emphasize formulas and mathematics procedures, not reasoning [21], [22]. Therefore, this research would like to develop an instructional material of mathematics logical thinking based on Indonesian Realistic Mathematics Education (IRME).

\section{Method}

This research is focusing on developing mathematics logical thinking for student worksheets based on Indonesian Realistic Mathematics Education. The model used in this research is design research with the type of development studies. Design Research is a developing model for designing and developing an intervention in learning, such as teaching programs, strategies, and learning materials [23]. Furthermore, Prahmana [24] states that what is meant by intervention in design research is to produce program designs, learning strategies, and instructional materials that can be used to solve problems in the process of learning or education empirically. This research used the type of development study. A development study is an activity of developing design principles for the field of practical benefit. The development research does in two stages: the preliminary and formative evaluation stages [25]. They include self-evaluation, prototyping (expert review and one-to-one (low resistance to revision), and small group) and field test (high resistance to correction). In the preliminary stage, the researcher set the place, research subject, and other preparations, including a schedule for doing research. The formative evaluation stage is divided into three phases, namely selfevaluation, prototyping, and field test.

Self-evaluation consists of two stages, namely the analysis and design stage. The analysis stage is the first stage in developing research. At this stage, researchers do student analysis, curriculum analysis, and content analysis. As for what will be analyzed in students is to analyze the ability of students in mathematics learning obtained from interviews with subject teachers. In this analysis, it is expected that researchers will get information about high, medium, and low levels of students. Next, for the curriculum analysis, that analyzed is 2013 curriculum mathematics subject was formed Core 
Competencies and Basic Competencies in the system, two variables linear equations used in junior high school. Besides, it will also be analyzed the book used in learning related to the operation of twovariable linear equations. In the design stage, the researcher designs the product to be developed, namely teaching materials in mathematical, logical thinking student worksheets based on Indonesian Realistic Mathematics Education. Designing student worksheets are done by prototyping using three characteristics: content, construct, and language. For more details, it can be seen in Table 1 .

Table 1. Focus of Prototype

\begin{tabular}{|c|c|c|}
\hline No & Characteristics & Information \\
\hline 1. & Content & $\begin{array}{l}\text { Suitable with several competency, namely core and basic } \\
\text { competencies, and indicators of competence achievement in } 2013 \\
\text { curriculum. } \\
\text { Student worksheet suitable with the concept of Indonesian Realistic } \\
\text { Mathematics Education. } \\
\text { The task or question practice in student worksheet suitable with the } \\
\text { indicator of logical thinking ability. }\end{array}$ \\
\hline 2. & Construct & $\begin{array}{l}\text { Student worksheet suitable with theory that supporting the criteria: } \\
\text { Developing logical thinking ability. } \\
\text { Rich in concepts } \\
\text { Suitable with student's grade 8th. }\end{array}$ \\
\hline 3. & Language & $\begin{array}{l}\text { Suitable EYD (official Indonesian spelling system) } \\
\text { Steps in student worksheet not convoluted. }\end{array}$ \\
\hline
\end{tabular}

Prototyping stages consist of three-phase, namely expert review, one-to-one, and small group. In this stage, the products that have been designed are evaluated. The steps of the evaluation that are passed are as follows.

Expert review is the stage where the experts of Indonesian Realistic Mathematics Education assess, evaluate, and validate student worksheets that have been designed by researchers so that the strengths and weaknesses of the student worksheets themselves are known. The basis of assessment for expert reviews is to assess whether the instructional material provided is by the RME-based instructional material, which is seen from the character and principles of RME in it. The assessment process is based on their expertise in RME's research. This stage aims to test the validity of the question that contains an indicator of logical thinking abilities in the student worksheets that have been developed, both in the form of content, constructs, and language used in this student worksheet. Experts assess, evaluate, and validate student worksheets that result from the prototype I design developed in the selfevaluation stage. From the expert review results, student worksheets were revised according to suggestions and comments from experts. Opinions and feedback from the expert (validator) about the worksheets that have been designed are written on the validation sheet as material to revise and state that the student worksheet is valid. The results of the prototype I revision at this stage are called prototype II.

One-to-one is a stage where the developed prototype I is tested on some students separately among one student and another. This stage is parallel with the expert review stage so that the revised results at this stage are used to edit the student worksheets designed in the prototype I to produce prototype II. A small group is a stage in which prototype II developed in expert review, and one-to-one is tested to some students who have different (heterogeneous) abilities. At this stage, six students are asked to discuss and learn the student worksheets that have been designed and asked to give comments or suggestions about the student worksheets. This trial aims to know the practicality of the instructional materials that have been developed. Based on feedback and suggestions from students, the student worksheets were revised to produce prototype III.

Lastly, the field test is a stage where the implementation of research with more students is the subject of study. Suggestions and results of trials on prototype II be based on revising prototype II design. The product tested in the field test stage must be a product that fulfills the quality criteria. There are three quality criteria: valid (from the expert), practical (easy to use) and can be used to developing the mathematics logical thinking skills of students (potential effects). 


\section{Results and Discussion}

The process of developing mathematics student worksheets consists of three stages. There is selfevaluation, prototyping (expert review, one-to-one, and small group) and field tests and revisions in each of these stages that have produced mathematics student worksheets based on Realistic Mathematics Education. Indonesia. Student worksheets that have been designed or prototype I are validated by experts. After the mathematics student worksheets based on Indonesian Realistic Mathematics Education were revised based on comments or suggestions from the validator presented in Table 2, the mathematics student worksheets based on Indonesian Realistic Mathematics Education were said to be valid.

Table 2. Comments or suggestion of the experts and researcher's feedback

\begin{tabular}{|c|c|c|}
\hline No & Comments & Revision Decision \\
\hline 1. & $\begin{array}{l}\text { If student worksheets, why should } \\
\text { there be a description of competencies } \\
\text { and so on. }\end{array}$ & $\begin{array}{l}\text { Omitting core competency sheets, essential } \\
\text { competencies, and indicators }\end{array}$ \\
\hline 2. & $\begin{array}{l}\text { PMRI-based student worksheets that } \\
\text { have been designed differently from } \\
\text { the RME-based student worksheets in } \\
\text { the Netherlands. }\end{array}$ & $\begin{array}{l}\text { After sending samples of worksheets in the } \\
\text { Netherlands, the researchers then reduced the text and } \\
\text { reproduced the images, just like the Dutch } \\
\text { worksheets where they used more image content than } \\
\text { text. }\end{array}$ \\
\hline 3. & $\begin{array}{l}\text { Realistic questions are not always in } \\
\text { the form of story problems. And story } \\
\text { matters are not necessarily realistic. }\end{array}$ & $\begin{array}{l}\text { Reinforce the concept of a realistic approach. Review } \\
\text { the practice questions that have been made }\end{array}$ \\
\hline
\end{tabular}

Mathematics student worksheets based on Indonesian Realistic Mathematics Education on the material of linear equations, two variables are said to be practically drawn from the observations through the trial process starting from one-to-one and small groups. The student worksheets developed were given to students in Sorong 9 Public Middle School in the one-to-one stage. After that, the student worksheets were revised based on comments or suggestions for improvement from students. After being revised, the mathematics student worksheets based on Indonesian Realistic Mathematics Education were piloted to six students in SMP Negeri 9 Sorong (small group) with different classes with students at the one-to-one stage. Students are given a mathematics student worksheet based on Indonesian Realistic Mathematics Education, then students learn and solve the questions contained in the student worksheet. Furthermore, students give comments/suggestions about the student worksheets that are developed. Each student was asked to respond about the legibility of the mathematics student worksheets, from the readability of students, which included the ease and difficulty in working on the mathematics student worksheets based on Indonesian Realistic Mathematics Education.

The student worksheets could be used in the learning process after the student worksheets were revised. The mathematics student worksheets used in the field test stage were practical, supported by an increase in students' mathematical logical thinking skills at the posttest. The results of improvement in mathematical, logical thinking skills in this study support the previous findings, which report that Indonesian Realistic Mathematics Education can improve students' mathematical logical thinking skills [13], [18], [26], [27]. The mathematics student worksheets prototype based on Indonesian Realistic Mathematics Education has been categorized as valid and practical. After that, it was tried out to research subjects, namely students of class VIII B Junior High School 9 Sorong. In the implementation of the learning process, it consists of three meetings. The first meeting is the pretest and the learning process. The second meeting is the learning process, and the third meeting is working on post-test questions. The students are given a pretest first before the student worksheets are tested. Lastly, students were given a posttest after the learning process using the mathematics student worksheets based on Indonesian Realistic Mathematics Education was completed posttest.

The data obtained from the pretest results before learning with teaching materials were analyzed quantitatively, which were then converted into qualitative data to determine the category of students' mathematical logical thinking skills, both per indicator and as a whole. The results of student work at the 
time of the pretest were corrected with the guidelines according to the scoring guidelines made so that quantitative data were obtained. Table 3 shows a summary of the student's pretest and posttest results.

Table 3. Pre-test and Post-test Score of Students

\begin{tabular}{cccccccccccc}
\hline No & Name & $\begin{array}{c}\text { Pre- } \\
\text { test }\end{array}$ & $\begin{array}{c}\text { Post- } \\
\text { test }\end{array}$ & No & Name & $\begin{array}{c}\text { Pre- } \\
\text { test }\end{array}$ & $\begin{array}{c}\text { Post- } \\
\text { test }\end{array}$ & No & Name & $\begin{array}{c}\text { Pre- } \\
\text { test }\end{array}$ & $\begin{array}{c}\text { Post- } \\
\text { test }\end{array}$ \\
\hline 1 & NSA & 3 & 19 & 11 & PY & 4 & 19 & 21 & HES & 4 & 19 \\
2 & AMK & 6 & 18 & 12 & WEU & 4 & 13 & 22 & AM & 0 & 18 \\
3 & ARA & 5 & 18 & 13 & Ris & 11 & 17 & 23 & GSU & 5 & 21 \\
4 & BM & 6 & 22 & 14 & Mar & 4 & 17 & 24 & DN & 4 & 12 \\
5 & AAS & 4 & 22 & 15 & FRA & 4 & 18 & 25 & BPL & 3 & 10 \\
6 & AAP & 4 & 19 & 16 & ER & 3 & 15 & 26 & JDK & 4 & 17 \\
7 & MIF & 7 & 18 & 17 & RL & 3 & 19 & 27 & MKT & 7 & 24 \\
8 & RPR & 9 & 17 & 18 & GPP & 4 & 14 & 28 & KK & 5 & 15 \\
9 & AZ & 7 & 17 & 19 & HS & 7 & 20 & 29 & KVM & 6 & 13 \\
10 & VW & 4 & 18 & 20 & CE & 0 & 12 & 30 & GSU & 5 & 21 \\
\hline
\end{tabular}

Furthermore, the post-test results of students' logical mathematics thinking abilities per indicator increased compared to the pretest results of students' logical mathematics thinking abilities per indicator. Students' logical mathematics thinking skills per indicator are spread into two categories in the post-test results, namely high understanding and sufficient understanding. The indicators of the relationship between facts are included in high performance. In contrast, indicators provide clear reasons, and indicators of the ability to conclude are in the category of sufficient understanding. For more details, it can be seen in Table 4.

Table 4. Pre-test and Post-test Score of Students

\begin{tabular}{|c|c|c|c|c|c|}
\hline No & $\begin{array}{c}\text { The indicator of logical } \\
\text { mathematics thinking } \\
\text { abilities }\end{array}$ & Pre-test & Category & Post-test & Category \\
\hline 1 & The relationship between facts & 2.69 & $\begin{array}{l}\text { Sufficient } \\
\text { understanding }\end{array}$ & 6.62 & $\begin{array}{l}\text { High } \\
\text { understanding }\end{array}$ \\
\hline 2 & Given clear reasons & 2.34 & $\begin{array}{l}\text { Sufficient } \\
\text { understanding }\end{array}$ & 5.48 & $\begin{array}{l}\text { Sufficient } \\
\text { understanding }\end{array}$ \\
\hline 3 & Conclusion ability & 2.07 & $\begin{array}{l}\text { Low } \\
\text { understanding }\end{array}$ & 5.17 & $\begin{array}{l}\text { Sufficient } \\
\text { understanding }\end{array}$ \\
\hline
\end{tabular}

Students have been able to solve mathematical, logical thinking problems better than before. Students' steps in answering questions can indicate the involvement of logical thinking and linking facts, giving reasons clearly and being able to conclude correctly [12], [28], [29]. From the results of the students' evaluation, students have been able to solve these problems by mathematical logical thinking indicators.

\section{Conclusion}

This research has been produced a teaching material development product in the form of student worksheets based on Indonesian Realistic Mathematics Education, which can be used to develop mathematical logical thinking skills. In this study, teaching materials based on Indonesian Realistic Mathematics Education were developed using the development studies of design research. The steps are in the form of a formative evaluation phase, including self-evaluation, prototyping (expert reviews, one-to-one, and small groups), and field tests. Mathematics student worksheets based on Indonesian Realistic Mathematics Education are categorically qualitatively valid. Valid is illustrated by the results of the validator's assessment, which contributes to suggestions and comments on improving mathematics student worksheets in terms of content, rent, and language. Validators state both based on content (material by necessary competences and following the steps of learning Indonesian Realistic Mathematics Education), constructs (developing mathematical logical thinking skills, rich in concepts, per eighth-grade), and language (according to EYD and uncomplicated questions). Furthermore, the mathematics student worksheets based on Indonesian Realistic Mathematics Education developed are categorized as practically qualitatively. Practically illustrated from the small 
group test observations, all students can use the mathematics student worksheets well. It shows that the mathematics student worksheets are by the characteristics of students. Lastly, researchers succeeded in developing teaching materials based on Indonesian Realistic Mathematics Education for VIII grade junior high school students who have potential effects. It is obtained from the posttest results and opinions of students during the interview at the field test stage. This situation is illustrated by the results of the posttest and the steps taken by students in answering questions (showing the involvement of logical thinking and linking facts, giving reasons clearly, and can conclude correctly).

\section{Acknowledgment}

The author would like to thank Universitas Ahmad Dahlan that supported this research. Furthermore, thanks to all participated students and teachers for their participation in this study.

\section{Declarations}

Author contribution $\quad$ : RP: Conceptualization, methodology, investigation, writing- original draft preparation; RCIP: Visualization, writing-reviewing-editing, and supervision.

Funding statement $\quad:$ No funding is available to declare for this paper.

Conflict of interest $\quad$ : The authors declare no conflict of interest.

Additional information : No additional information is available for this paper.

\section{References}

[1] Depdiknas, Panduan Penyusunan Kurikulum Tingkat Satuan Pendidikan. Jakarta: Badan Standar Nasional Pendidikan, 2006, available at: Google Scholar.

[2] I. Ambussaidi, \& Y.F. Yang, "The impact of mathematics teacher quality on student achievement in Oman and Taiwan," International Journal of Education and Learning, vol. 1, no. 2, pp. 50-62, 2019. doi: 10.31763/ijele.v1i2.39.

[3] I. Nuraida, \& A. Amam, "Hypothetical learning trajectory in realistic mathematics education to improve the mathematical communication of junior high school students," Infinity Journal, vol. 8, no. 2, pp. 247258, 2019. doi: 10.22460/infinity.v8i2.p247-258.

[4] M. Asis et al., "Profil kemampuan spasial dalam menyelesaikan masalah geometri siswa yang memiliki kecerdasan logis matematis tinggi ditinjau dari perbedaan gender," Jurnal Daya Matematis, vol. 3, no. 1, pp. 78-87, 2015, doi: 10.26858/jds.v3i1.1320.

[5] S. Psycharis, \& M. Kallia, "The effects of computer programming on high school students' reasoning skills and mathematical self-efficacy and problem solving," Instructional Science, vol. 45, no. 5, pp. 583602, 2017, doi: 10.1007/s11251-017-9421-5.

[6] D. M. Sari et al., "Analysis of students' prior ability in mathematical logical thinking ability," Advanced Journal of Technical and Vocational Education, vol. 2, no. 1, pp. 13-18, 2018, doi: 10.26666/rmp.ajtve.2018.1.3.

[7] D. Usdiyana et al., "Meningkatkan kemampuan berpikir logis siswa smp melalui pembelajaran matematika realistik," Jurnal Pengajaran MIPA, vol. 13, no. 1, pp. 1-14, 2009, doi: 10.18269/jpmipa.v13i1.300.

[8] P. Singh et al., "The use of problem-solving heuristics approach in enhancing STEM students development of mathematical thinking," International Electronic Journal of Mathematics Education, vol. 13, no. 3, pp. 289-303, 2018, doi: 10.12973/iejme/3921.

[9] E. Suryawati, \& K. Osman, "Contextual learning: Innovative approach towards the development of students' scientific attitude and natural science performance," Eurasia Journal of Mathematics, Science and Technology Education, vol. 14, no. 1, pp. 61-76, 2017, doi: 10.12973/ejmste/79329.

[10] M. Estai, \& S. Bunt, S, "Best teaching practices in anatomy education: A critical review," Annals of Anatomy-Anatomischer Anzeiger, vol. 208, pp. 151-157, 2016, doi: 10.1016/j.aanat.2016.02.010 
[11] R. C. I. Prahmana, "Permainan "tepuk bergilir" yang berorientasi konstruktivisme dalam pembelajaran konsep kpk siswa kelas IV A di SD N 21 Palembang," Jurnal Pendidikan Matematika, vol. 4, no. 1, pp. 61-69, 2010, doi: 10.22342/jpm.4.2.406.

[12] S. Revina, \& F. K. S. Leung, "Educational borrowing and mathematics curriculum: Realistic Mathematics Education in the Dutch and Indonesian primary curriculum," International Journal on Emerging Mathematics Education, vo. 2, no. 1, pp. 1-16, 2018, doi: 10.12928/ijeme.v2i1.8025.

[13] P. Yuanita et al., "The effectiveness of Realistic Mathematics Education approach: The role of mathematical representation as mediator between mathematical belief and problem solving," PloS one, vol. 13, no. 9, pp. e0204847, 2018, doi: 10.1371/journal.pone.0204847.

[14] K. Gravemeijer, Developing Realistic Mathematics Education. Utrecht: Freudenthal Institute, 1994, available at: Google Scholar.

[15] J. de Lange, Mathematics, Insight, and Meaning. Utrecht: OW\&OC, 1987, available at: Google Scholar.

[16] Zulkardi, Developing A Learning Environment on Realistic Mathematics Education for Indonesian Student Teachers. Enschede: University of Twente, 2002, available at: Google Scholar.

[17] R.C.I. Prahmana et al., "Learning Multiplication Using Indonesian Traditional Game in Third Grade," Journal on Mathematics Education, vol 3, no. 2, pp. 115-132, 2012, doi: 10.22342/jme.3.2.1931.115132.

[18] T. Laurens et al., "How does realistic mathematics education (RME) improve students' mathematics cognitive achievement?," Eurasia Journal of Mathematics, Science and Technology Education, vol. 14, no. 2, pp. 569-578, 2017, doi: 10.12973/ejmste/76959.

[19] R. K. Sembiring et al., "Reforming mathematics learning in Indonesian classrooms through RME," ZDM, vol 40, no. 6, pp. 927-939, 2008, doi: 10.1007/s11858-008-0125-9.

[20] A. Prastowo, Panduan Kreatif Membuat Bahan Ajar Inovatif. Yogyakarta: DIVA Press, 2011, available at: Google Scholar.

[21] A. Wijaya et al., "Opportunity-to-learn to solve context-based mathematics tasks and students' performance in solving these tasks-lessons from Indonesia," EURASIA Journal of Mathematics, Science and Technology Education, vol. 14, no. 10, pp. em1598, 2018, doi: 10.29333/ejmste/93420.

[22] A. Wijaya et al., "Opportunity to learn context-based tasks provided by mathematics textbooks," Educational Studies in Mathematics, vol. 89, no. 1, pp. 41-65, 2015, doi: 10.1007/s10649-015-9595-1.

[23] T. Plomp, \& N. Nieveen, Educational design research: An introduction. In T Plomp and N Nieveen (Eds.) Educational Design Research (pp. 10-51). Enschede: Netherlands Institute for Curriculum Development (SLO), 2013, available at: Google Scholar.

[24] R. C. I. Prahmana, Design Research (Teori dan Implementasinya: Suatu Pengantar). Depok: Rajawali Pers, 2017, Available at: Google Scholar.

[25] D. Mardhiyanti et al., "Pengembangan soal matematika model PISA untuk mengukur kemampuan komunikasi matematis siswa sekolah dasar,” Jurnal Pendidikan Matematika, vol. 5, no. 1, pp. 16-29, 2013, doi: 10.22342/jpm.5.1.334.

[26] M. Saleh et al., "Improving the reasoning ability of elementary school student through the Indonesian Realistic Mathematics Education," Journal on Mathematics Education, vol. 9, no. 1, pp. 41-54, 2018, doi: 10.22342/jme.9.1.5049.41-54.

[27] M.S. Athumani et al., "Confirmatory factor analysis of self-evaluation spatial thinking skills (SESS) measurement model," International Journal of Education and Learning, vol. 2, no. 1, pp. 1-6, 2020, doi: 10.31763/ijele.v2i1.80.

[28] Y. Ariani et al., "Edmodo social learning network for elementary school mathematics learning," Journal of Physics: Conference Series, vol. 943, no. 1, pp. 012056, 2018, doi: 10.1088/1742-6596/943/1/012056.

[29] R. C. I. Prahmana et al., "Learning multiplication using Indonesian traditional game in third grade," Journal on Mathematics Education, vol. 3, no. 2, pp. 115-132, 2012. doi: 10.22342/jme.3.2.1931.115132. 